Supplement to the Flora of Whatcom County, Washington. Madroño 11: 161-162. Oct 1951.

Aquatic Plants in Ozette Lake, Washington. Madroño 11: 184-186. Oct 1951.

A Sphagnum Paradise. Bryologist 54: 267-269. Dec 1951. With Babette I. Brown.

The Vegetation of Bergen Swamp. IX. Supplement. Proc. Rochester Acad. Sci. 9: 339-347. Dec 1951.

[Review of] Algae of the Western Great Lakes Area. (G. W. Prescott.) Jour. Wildlife Management 16(1). Jan 1952.

Weeds appear in Beebe Lake. Cornell Plantations 8: 53-55. Summer 1952.

Some unusual plants. Cornell Plantations 8: 74-76. Summer 1952.

Herb recollections-Ruta graveolens. Herb Grower 6: 150. (Illustration by Elfriede Abbe). 1952.

Plankton algae of some lakes of Whatcom County, Washington. Madroño 11: 289-297. Oct 1952. With George J. Schumacher.

A check list of the more common plants of Bergen Swamp. Published by the Bergen Swamp Preservation Society, Inc., Rochester, N. Y. 1953.

Herb recollections. II-Good King Henry. Herb Grower 7: 10. (Illustration by Abbe). Spring 1953.

Tulip tree by Beebe Lake. Cornell Plantations 9(4): 55. Summer 1953.

Herb recollections. III-Costmary. Herb Grower 7: 57. (Illustration by Abbe). Summer 1953.

Herb recollections. IV-Lovage. Herb Grower 7: 112. (Illustration by Abbe). Autumn 1953.

List of weeds of New York. Cornell Extension Bull. 891. Dec 1953. With G. J. Schumacher.

Garden spice and wild potherbs. (With illustrations cut on wood by Elfriede Abbe). Printed by Elfriede Abbe, Ithaca, N. Y. 1954. Limited edition, 90 copies, published Feb 1955. With Myron A. Rice.

Garden spice and wild pot-herbs. Popular edition published Oct 1955, second printing, Jan 1956. Comstock Publishing Associates, Ithaca, N. Y. With Myron A. Rice.

Weeds. xvi, 560 p. Ed. 2. Macmillan Co., New York. 1955.

The Characeae of the State of New York. Cornell Univ. Agr. Exp. Sta. Mem. 338. Apr 1956. With R. D. Wood.

A distributional study of the epiphytic plants of the Olympic Peninsula, Washington. Am. Mid. Nat. 56: 54-87. Jul 1956. With Babette B. Coleman and D. R. Charles.

Poison ivy and poison sumac. Cornell Ext. Bull. 191. Rev. 1957. With J. M. Kingsbury.

Culinary herbs. Cornell Ext. Bull. 841. Rev. Mar 1963. With Myron A. Rice and Babette I. Brown.

Articles on Poisonous Plants, Poison Ivy, Weeds and several specific weedy plants in 1951, 1957 and 1961 editions of the Encyclopedia Brittanica.

Weeds articles in 1956 and 1961 editions of The World Book Encyclopedia.

\title{
CLOSING DATES FOR RESEARCH PROPOSALS, NATIONAL SCIENCE FOUNDATION
}

The Division of Biological and Medical Sciences of the National Science Foundation announces that there will no longer be closing dates for receipt of basic research proposals in the Life Sciences. Proposals will be received all year, and will be reviewed by the Foundation's advisory panels usually three times during the calendar year. Applicants should allow 6 months between the time the Foundation receives a proposal and the notification of its decision regarding support.

Inquiries should be addressed to the Division of Biological and Medical Sciences, National Science Foundation, Washington, D. C. 20550. 